\title{
Strategi Pengembangan Wisata Berbasis Kearifan Lokal pada Desa Wisata Pagerharjo Kecamatan Samigaluh Kabupaten Kulon Progo Yogyakarta
}

\author{
Sukmadi Sukmadi', Faisal Kasim², Violetta Simatupang ${ }^{3}$, Andar Danova L. Goeltom ${ }^{4}$, \\ Indra Saftara ${ }^{5}$ \\ Sekolah Tinggi Pariwisata Bandung, Indonesia ${ }^{1,2,3,4,5}$ \\ Email: dr.sukmadi@gmail.com
}

\begin{abstract}
This study aims to identify and analyze tourism development strategies based on local wisdom in the tourism village of Pagerharjo, Samigaluh District, Kulon Progo Regency, Yogyakarta. The method used in this study is a descriptive qualitative method with a case study approach. Sources of data in this study are primary funds and secondary data. Primary data were obtained through interviews and field observations. While the data analysis technique used is data analysis using the interactive model of analysis developed by Miles and Hubermann. The results showed that (1) The potential of local wisdom that can be packaged and developed as a tourist attraction in the Tourism Village of Pagerharjo is mutual cooperation, nguri-uri oral traditions, suronan, reog cultural traditions, jathilan, incling, angguk, campur sari, kethoprak, puppeteer and what is characteristic is the lengger tapeng dance, while from a culinary perspective there is taro leaf butyl, geblek, which can still be witnessed and enjoyed today; (2) Aspects that must be considered in planning tourism development in the Tourism Village of Pagerharjo are (a) the low level of community human resources in the development of tourism villages; (b) Poor tourism village institutional governance; (c) Low optimization of local products (food, crafts, arts); (d) The absence of participatory planning in the development of tourism villages; (3) The supporting factors for the development of tourism based on local wisdom in the Tourism Village of Pagerharjo include the community culture that has been attached to the attitude of courtesy and hospitality to anyone who comes. While the inhibiting factors include the absence of a blueprint for mapping the tourism potential in Pagerharjo village, community empowerment from upstream to downstream which has not been running and communication factors between the community, village government and all elements involved in it need to be improved so that harmonious communication is formed
\end{abstract}

Keywords: Tourism Development Strategy; Local Wisdom; Tourism Village.

\begin{abstract}
Abstrak
Penelitian ini bertujuan untuk mengetahui dan menganalisis strategi pengembangan wisata berbasis kearifan lokal pada desa wisata Pagerharjo Kecamatan Samigaluh Kabupaten Kulon Progo Yogyakarta. Metode yang digunakan dalam penelitian ini adalah metode kualitatif deskriptif dengan jenis pendekatan studi kasus. Sumber data dalam penelitian ini adalah dana primer dan data sekunder. Data primer diperoleh melalui wawancara dan observasi di lapangan. Sedangkan tehnik analisis data yang digunakan adalah analisis data dengan menggunakan interactive model of analysis yang dikembangkan oleh Miles dan Hubermann. Hasil penelitian menunjukkan bahwa (1) Potensi kearifan lokal yang dapat dikemas dan dikembangkan sebagai daya tarik wisata di Desa Wisata Pagerharjo adalah guyup rukun dan gotong royong, nguri-uri tradisi mulutan, suronan, tradisi budaya reog, jathilan, incling, angguk, campur sari, kethoprak, pendalangan dan yang menjadi ciri khas adalah tari lengger tapeng, sedangkan dari segi kuliner ada butil daun talas, geblek yang mana hal tersebut masih bisa disaksikan dan dinikmati sampai saat ini; (2) Aspek yang harus dipertimbangkan dalam perencanaan pengembangan wisata di Desa Wisata Pagerharjo adalah (a) Rendahnya SDM masyarakat dalam pengembangan desa wisata; (b) Tata kelola kelembagaan desa wisata yang tidak baik; (c) Rendahnya optimalisasi produk lokal (makanan, kerajinan, kesenian) ; (d) Tidak adanya perencanaan partisipatif dalam pengembangan desa wisata; (3) Faktor pendukung pengembangan wisata berbasis kearifan lokal di Desa Wisata Pagerharjo diantaranya adalah kultur masyarakat yang sudah melekat dengan sikap sopan santun serta ramah tamah kepada siapapun yang datang. Sedangkan faktor penghambat diantaranya adalah belum adanya blueprint pemetaan potensi wisata yang ada di desa Pagerharjo, pemberdayaan masyarakat dari hulu ke hilir yang belum berjalan
\end{abstract}

* Corresponding author

Received: Octobber 21, 2020; Revised: November 13, 2020; Accepted: December 21, 2020 
serta faktor komunikasi antara masyarakat, pemerintah desa dan semua elemen yang terlibat didalamnya perlu ditingkatkan sehingga terbentuk komunikasi yang harmonis.

Kata Kunci: Strategi Pengembangan Wisata; Kearifan Lokal; Desa Wisata.

\section{A. PENDAHULUAN}

Pariwisata adalah sebuah kegiatan yang dilakukan hampir seluruh manusia di muka bumi. Kegiatan pariwisata sangat kompleks, mencakup seluruh aspek kehidupan. Menurut Maryani (2013:6) pariwisata merupakan salah satu kebutuhan yang tidak dapatdihindarkan khususnya bagi masyarakat perkotaan disaat menghadapi situasi padat jam kerja, sibuk dan hiruk pikuknya suasana kota, terbatasnya lahan-lahan terbuka (open space) dan taman-taman bermain untuk anak-anak atau remaja, serta kejenuhan- kejenuhan lain.

Potensi wisata dari lingkup kota, kabupaten, hingga yang terkecil yaitu desa, mulaidipasarkan demi meningkatkan lapangan kerja meningkatkan pendapatan, serta mendukung perkembangan usaha kecil di daerah masing -masing. Wilayah yang memiliki potensi wisata yang cukup besar salah satunya adalah Kabupaten Kulon Progo yang membuktikan perkembangan dan eksistensinya dengan cara menawarkan daya tarikwisata alam. Daya tarik wisata adalah segala sesuatu yang memiliki keunikan, keindahan,dan nilai berupa keanekaragaman kekayaan alam, budaya, dan hasil buatan manusia yang menjadi sasaran atau tujuan kunjungan Wisatawan.

Desa Wisata merupakan pengembangan suatu wilayah desa yang pada dasarnya tidak merubah apa yang sudah ada akan tetapi lebih cenderung kepada pengembangan potensi desa yang ada dengan melakukan pemanfaatan kemampuan unsur- unsur yang ada di dalam desa yang berfungsi sebagai atribut produk wisata dalam skala yang kecil menjadi rangkaian aktivitas atau kegiatan pariwisata dan mampu menyediakan serta memenuhi serangkaian kebutuhan perjalanan wisata baik dari aspek daya tarik maupun sebagai fasilitas pendukung. Pengembangan Desa Wisata merupakan suatu upaya yang di gunakan untuk memanfaatkan sumberdaya alam dengan sebaik-baiknya untuk menarikminat wisatawan sehingga dapat menguntungkan dan dapat mensejahterakan masyarakatsekitarnya.

Salah satu Desa yang memiliki keistimewaan wisata alam, budaya, dan agro adalah Desa Pagerharjo yang terletak di Kecamatan Samigaluh. Tiga kebutuhan utama yang harus dipenuhi oleh suatu daerah untuk menjadi tujuan wisata, antara lain memilikiatraksi atau objek menarik, mudah dicapai dengan kendaraan, menyediakan tempat tinggal sementara. Desa Pagerharjo masuk dalam ketiga kategori tersebut. Tidak hanya itu, Pagerharjo menjadi daerah tujuan wisara tergantung atas kebudayaan, yaitu tempat yang mempunyai acara khusus seperti perayaan, adat istiadat, pesta rakyat dan lain sebagainya.

Nilai dan budaya lokal Desa Pagerharjo dapat menjadi acuan dalam desain, antaralain bentuk bangunan lokal, aksen-aksen yang ada didalam komponen kesenian, dan cirikhas lansekap yang ada di lokasi tersebut. Kekuatan identitas kawasan di wilayah Pagerharjo itulah yang menjadi dasar atau landasan dalam memperkuat desain bangunan.Tempat dan ruang tertentu memiliki potensi fisik, sosial, dan ekonomi dan secara kultur memiliki batas-batas arsitektural maupun sejarah. Dengan demikian arsitektur regional mengacu pada tradisi, warisan sejarah serta makna ruang dan tempat. Bangunan bersifat abadi dan melebur antara yang lama dan yang baru, kemudian aplikasi desain mampu mencerminkan budaya setempat sekaligus mengadopsi teknologi baru. Arsitektur regional secara langsung mendukung program Kabupaten Kulon Progo dalam peraturan zonasi kawasan peruntukan pariwisata, yaitu diperbolehkan dalam mengembangkan kawasan pariwisata namun tetap memperhatikan nilai budaya setempat.

Penelitian ini bertujuan untuk mengetahui dan menganalisis (1) Apa saja potensi kearifan lokal yang dapat dikemas dan dikembangkan sebagai daya tarik wisata di Desa Wisata Pagerharjo; (2) Aspek 
apa saja yang harus dipertimbangkan dalam perencanaan pengembangan wisata di Desa Wisata Pagerharjo; dan (3) Apa saja faktor pendukung danpenghambat pengembangan wisata berbasis kearifan lokal di Desa Wisata Pagerharjo.

\section{B. TINJAUAN PUSTAKA}

\section{Pengembangan Pariwisata}

Strategi pengembangan pariwisata menurut Rangkuti (2013: 3) sebagaimanamengutip Chandler, strategi merupakan suatu alat untuk mencapai tujuan dalam kaitannya dengan jangka panjang, program tindak lanjut serta prioritas sumber daya. Selanjutnya menurut Marpaung (2007: 19) :"perkembangan kepariwisataan bertujuan memberikankeuntunganbaik bagi wisatawan maupun warga setempat. Pariwisata dapat memberikan kehidupan yang standar kepada warga setempat melalui keuntungan ekonomi yang didapat dari tujuan wisata. Dalam perkembangan infrastruktur danfasilitas rekreasi, keduanya menguntungkan wisatawan dan warga setempat, sebaliknya kepariwisataan dikembangkan melalui penyediaan tujuan tempatwisata".

Menurut Suwardjoko (2017) pengembangan obyek wisata harus memenuhi dua hal yaitu penampilan eksotis suatu obyek pariwisata dan pemenuhan kebutuhan manusiasebagai hiburan waktu senggang/leissure. Dengan kata lain pengangkatan suatu potensi wisata bisa dikatakan berhasil jika penampilannya unik, khas dan menarik dan waktu pelaksanaannya sesuai dengan waktu luang yang dimiliki calon wisatawan.

Menurut Pratiwi (2015: 1074) pengembangan kepariwisataan membawa banyak manfaat dan keuntungan. Oleh karena itu pembangunan kepariwisataan diarahkan pada peningkatan pariwisata menjadi sector andalan yang mampu mengalahkan kegiatanekonomi termasuk kegiatan sector lain yang terkait. Sehingga lapangan kerja, pendapatanmasyarakat, pendapatan daerah dan pendapatan Negara serta penerimaan devisa meningkat melalui usaha pengembangan dan pendayagunaan berbagai potensi kepariwisataan.

\section{Pengembangan Desa Wisata}

Desa wisata adalah suatu bentuk perkembangan pariwisata yang menitik beratkanpada kontribusi masyarakat sekitar pedesaan dan pelestarian lingkungan area pedesaan. Desa wisata memiliki produk wisata yang benilai budaya dan memiliki karakteristik traditional yang kuat (Fandeli, Baiquni, Dewi, 2013) Begitupun menurut Inskeep (2015) mendefinisikan wisata pedesaan yang dimana sekelompok wisatawan tinggal dalam suasana yang tradisional, tinggal di desa untuk mempelajari kehidupan di pedesaan. Menurut Peraturan Kementrian Kebudayaan dan Pariwisata, desaiwisata adalah suatu bentuk kesatuan antara akomodasi,atraksi,, sarana dan prasarana pendukung wisata yangdisajikan dalam suatu tatanan kehidupan masyarakat yang menyatu dengan tradisi yang berlaku.

Pengembangan desa wisata akan berhasil jika semua potensi desa seperti sumberdaya manusia dan potensi alam yang dimiliki dapat disinergikan secara maksimal.Tentunya pengembangan desa wisata harus mendapat dukungan dan pemerintah desa setempat dan masyarakatnya. Pengembangan desa wisata akan membuka peluang penyerapan tenaga kerja, transaksi perdagangan produk asli daerah juga akan meningkatyang pada akhirnya akan berimlikasi pada peningkatan ekonomi masyarakat desa tersebut. Desa wisata adalah suatu wilayah pedesaan yang menawarkan keaslian baik darisegi sosial budaya, adat istiadat, keseharian, arsitektur tradisional, struktur tata ruang desayang disajikan dalam suatu bentuk integrasi komponen pariwisata antara lain seperti atraksi, akomodasi dan fasilitas pendukung (Zakaria, 2014). Konsep desa wisata menurutKemenparekraf (2014) adalah sebagai berikut: 


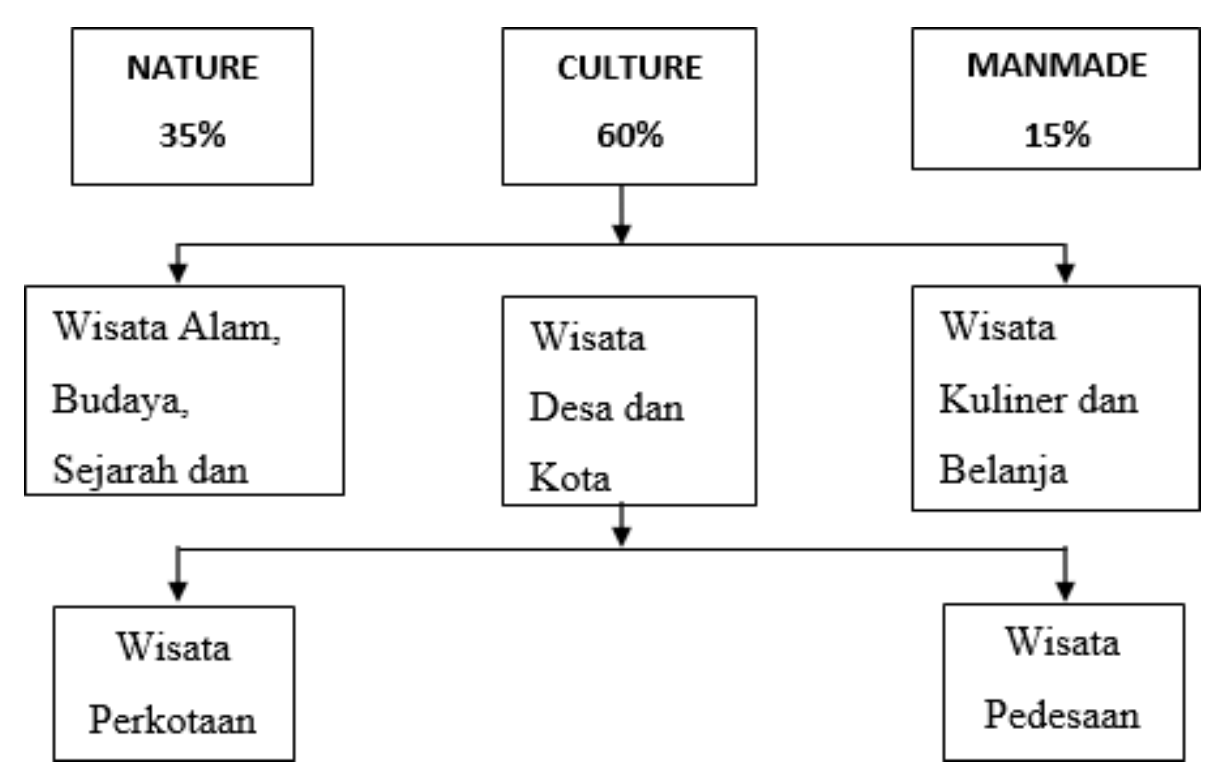

\section{Gambar 1 Konsep Desa Wisata}

\section{Sumber : Kemenparekraf, (2014)}

\section{Kearifan Lokal}

Menurut Suaib (2017) kearifan local atau local wisdom merupakan gagasan- gagasan atau nilainilai, pandangan-pandangan setempat atau (lokal) yang bersifat bijaksana, penuh kearifan bernilai baik yang tertanam dan diikuti oleh anggota masyarakatnya. Kearifan lokal adalah kebijakan atau pengetahuan asli suatu masyarakatyang berasal dari nilai luhur tradisi budaya untuk mengatur tatanan kehidupan masyarakat. Dengan demikian, nilai-nilai kearifan local yang terkandung dalam suatu ekosistem masyarakat, dapat dihayati, dipraktikan, diajarkan dan diwariskan dari suatu generasi ke generasi lainnya yang sekaligus membentuk dan menuntun pola prilaku manusia sehari-hari, baik terhadap lingkungan.

Kearifan lokal merupakan modal utama masayarakat dalam membangun dirinya tanpa merusak tatanan social adaptif dengan lingkungan alam sekitranya. Kearifan lokaldi bangun dari nilai-nilai sosial yang di junjung dalam struktur sosial masyarakat sendiri dan memiliki fungsi sebagai pedoman, pengontrol dan rambu-rambu untuk berprilaku dalam berbagai kehidupan baik saat berhubungan dengan sesama maupun dengan alam (Theresia, 2015).

Dalam kearifan lokal, terkandug pula kearifan budaya lokal. Kearifan lokal sendiri adalah pengetahuan lokal yang sudah sedemikian menyatu dengan system kepercayaan, norma, dan budaya serta diekspresikan dalam tradisi dan mitos yang dianut dalam jangkawaktu yang lama. Jadi, untuk melaksanakan pembangunan di suatu daerah, hendaknya pemerintah mengenal lebih dulu seerti apakah pola pikir dan apa saja yang ada pada daerah yang menjadi sasaran pembangunan tersebut adalah sangat membuang tenaga dan biaya juga membuat tempat wisata tanpa memberi pembinaan kepada masyarakat setempat bahwa tempat tersebut adalah "ikon" atau sumber pendapatan yang mampu mnyejahterakan rakyat didaerah itu. Atau lebih sederhananya pembangunan akan menjadisia-sia jika pemerintah tidak mengenal masyarakat atau potensi yang tepat untuk pembangunan di daerah tersebut.

\section{Strategi Pengembangan Wisata berbasis Kearifan Lokal}

Pengembangan desa wisata berbasis kearifan lokal merupakan kegiatan yang tidakmudah untuk dilakukan apabila tidak didukung oleh seluruh komponen masyarakat yangada di dalam desa tersebut. 
Sebagai contoh adalah potensi kearifan lokal yang ada sepertikegiatan panen padi yang di awali menggunakan upacara tertentu, ritual meminta hujan dan sebagainya. Hal ini tidak akan menjadi suatu potensi kearifan lokal jika dilakukan secara insidental oleh masing-masing pribadi pemilik lahan. Potensi yang seharusnya muncul di di permukaan sebagai kegiatan budaya tidak terlihat karena tidak dilakukan secara komunal dan dikemas, diagendakan oleh seluruh pemilik lahan sawah ataupun masyarakat tertentu maka akan menjadi sebuah atraksi wisata menarik.

Sebagai Strategi pengembangan desa wisata melalui kearifan lokal mengacu padapotensi fisik dan non fisik yang terdapat pada masing- masing desa yang akan dikembangkan, hal ini berkaitan dengan kekhasan masing-masing desa dalam menjual potensinya untuk dijadikan modal dasar sebagai desa wisata. Strategi pengembangan desawisata berbasis kearifan lokal perlu memperhatikan hal-hal sebagai berikut (Repastri 2012):

a) Pemasaran paket desa wisata yang menunjukkan nilai jual desa tersebut.

b) Pengelolaan desa wisata yang berkelanjutan dan menjaga kelestarian desa wisata itu sendiri.

c) Pemberdayaan masyarakat desa wisata itu sendiri sebagai bagian dari potensi desawisata tersebut.

d) Kemasan desa wisata yang tidak monoton sehingga tidak memberikan kesan biasasaja kepada pengunjung.

e) Menghindari adanya konflik kepentingan di antara desa-desa wisata yang berdekatan.

f) Dapat meningkatkan perekonomian masyarakat desa yang dijadikan desa wisata.

Dalam suatu desa wisata umumnya terdapat potensi fisik maupun non fisik, potensi fisik dapat diatur dengan mudah sedemikian rupa, akan tetapi potensi non fisik perlu adanya pendekatan sosial budaya yang mendalam. Potensi sosial budaya yang akandikembangkan sebagai kearifan lokal dapat menjadi bumerang bagi desa wisata dalam pengembangannya apabila tidak dilakukan pendekatan dengan baik, misalnya jika masyarakat di desa wisata tersebut 6 adalah masyarakat heterogen maka dapat timbul kelompok-kelompok berdasar agama, ras, silsilah keluarga, status ekonomi, dan lain-lain. Namun demikian jika ada pendekatan yang cukup baik, justru keheterogenan tersebut dapat dijadikan potensi yang menguntungkan untuk pengembangan desa wisata (Repasti,2012).

\section{METODOLOGI PENELITIAN}

Metode yang digunakan dalam penelitian ini adalah metode kualitatif deskriptif dengan jenis pendekatan studi kasus (Singarimbun, 2013:4). Penelitian kualitatif mempunyai tujuan agar peneliti lebih mengenal lingkungan penelitian, dan dapat terjun langsung ke lapangan sebagai key instrument (instrumen kunci).

Dalam setiap penelitian disamping menggunakan metode yang tepat juga diperlukan kemampuan memilih metode pengumpulan datayang relevan. Data merupakan faktor penting dalam penelitian, kerena di dalam setiap penelitian pasti memelukan data. Sumber data yang digunakan dalam penelitian ini adalah dana primer dan data sekunder. Data primer diperoleh melalui wawancara dan observasi di lapangan sedangkan data sekunder dalam penelitian ini adalah teks-teks berita mengenai strategi pengembangan pariwisata, buku-buku, dan dokumentasi lain yang berkaitan dengan penelitian.

Tehnik analisis data yang digunakan adalah analisis data dengan menggunakan interactive model of analysis (analisis model interaktif) yang dikembangkan oleh Miles dan Hubermann. Pada model interaktif ini berfokus pada tiga komponen, yaitu reduksi data (data reduction), data display, dan coclusion drawing yaitu terdiri dari tahappenarikan dan verifikasi (Miles dan Hubermann, 2012:25). Proses analisis interaktif ini dapat disajikan dalam bentuk Gambar 2. berikut ini: 


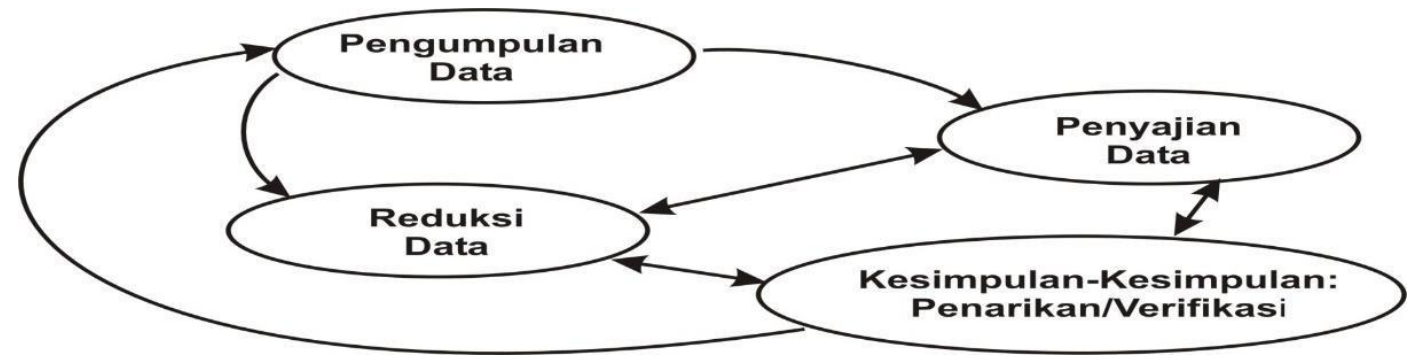

Gambar 2 Analisis Data Model Interaktif

Sumber : Miles dan Hubermann (2012: 34)

\section{HASIL DAN PEMBAHASAN}

\section{Profil Desa Pagerharjo}

Desa Pagerharjo berjarak $6 \mathrm{~km}$ dari ibukota kecamatan samigaluh, dengan luasdesa 1.140,52 atau 16,46\% dari total luas kecamatan samigaluh, desa ini terdiri dari 20 Pedukuhan dengan jumlah RT : 87 dan RW : 43. Desa Pagerharjo memiliki konfigurasi lahan antara lain tanah persawahan, tanah kering, bangunan, hutan rakyat,dan lainnya. Sebagian besar penduduk Pagerharjo memiliki mata pencaharian yaitu petani dan berkebun. Hasil perkebunan kemudian dijual keluar wilayah untuk menjaditambahan perekonomian. Tanah kering yang berada di Desa Pagerharjo memiliki fungsi untuk menanam berbagai tanaman produktif individu. Karakteristik tanah di daerah pegunungan Menoreh rata-rata merupakan tanah subur yang dapat ditanami berbagai macam tumbuhan produktif.

\section{Potensi kearifan lokal yang dapat dikemas dan dikembangkan sebagai daya tarik wisata di Desa Wisata Pagerharjo}

Peraturan Daerah Kulon Progo menjelaskan bahwa hampir seluruh kecamatandi Kulon Progo merupakan kawasan peruntukan pariwisata, dengan penunjang tiap kecamatannya. Setiap kecamatan memiliki karakteristik kawasan yang berbeda - beda. Bahkan perbedaan karakteristik terdapat pada Desa di Kulon Progo. Secara keseluruhan, wilayah di Kabupaten Kulon Progo memiliki potensi yang cukup besar untuk mengembangkan kawasan wisata, yang kemudian berdampak pada penambahan perekonomian wilayah.

Rencana tata ruang menunjukkan bahwa Desa Pagerharjo yang terletak di Kecamatan Samigaluh memiliki potensi yang cukup besar untuk membuat sebuah kawasan pariwisata baru yang dapat mendukung keseluruhan program kerja pemerintah. Selain itu, meningkatnya produk wisata di Desa Pagerharjo menimbulkanrespon antara lain penambahan produk wisata yang mencangkup keseluruhan jenis wisata yaitu budaya, alam dan buatan untuk mendukung tiap objek di Pagerharjo. Strategi dalam meningkatkan kawasan pariwisata antara lain dengan mengoptimalkan potensi wisata, mengingkatkan sarana dan prasarana pendukung, pengembanganproduk wisata, efektifitas promosi dan meningkatkan sinergi jasa pelayanan pariwisata. Usaha peningkatan kawasan pariwisata tidak dapat dilakukan tanpa mempertimbangkan fungsi kawasan lindung di Kabupaten Kulon Progo. Kegiatan yang dilakukan yaitu dengan melakukan pengawasan dan pemantauan kegiatan pariwisata yang berpotensi menurunkan kualitas hutan lindung, serta melestarikan keanekaragaman hayati untuk di daerah Bukit Menoreh dan sekitarnya. 
Potensi wilayah di Desa Pagerharjo yang paling menonjol adalah objek wisataalam dan budaya. Wisata alam terdiri dari air terjun, kebun teh, dan hutan pinus. Wisata budaya terdiri dari Jathilan dan jenis pertunjukan lain. Adapun peta wisata Desa Pagerharji dapat dilihat pada gambar berikut:

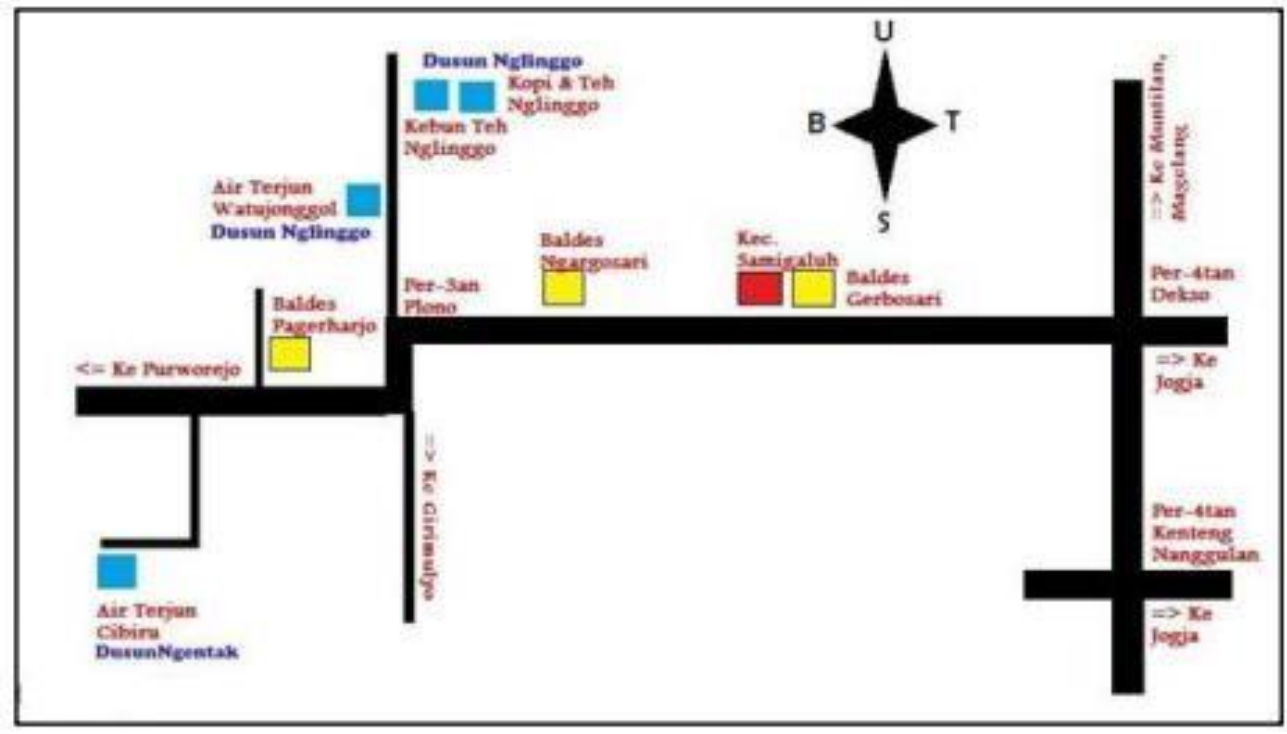

\section{Gambar 3 Peta Wisata Desa Pagerharjo}

Potensi alam di Desa Pagerharjo yang pertama adalah kebun teh Misi Nglinggo. Kebun teh menjadi tren wisata alam di Pagerharjo karena keunikannya. Misi merupakankebun teh yang mudah dijangkau oleh wisatawan dari wilayah Yogyakarta sekitarnya. Wisatawan yang menuju kebun teh antara lain dari Yogyakarta, Kabupaten Magelang, dan Kabupaten Purworejo.
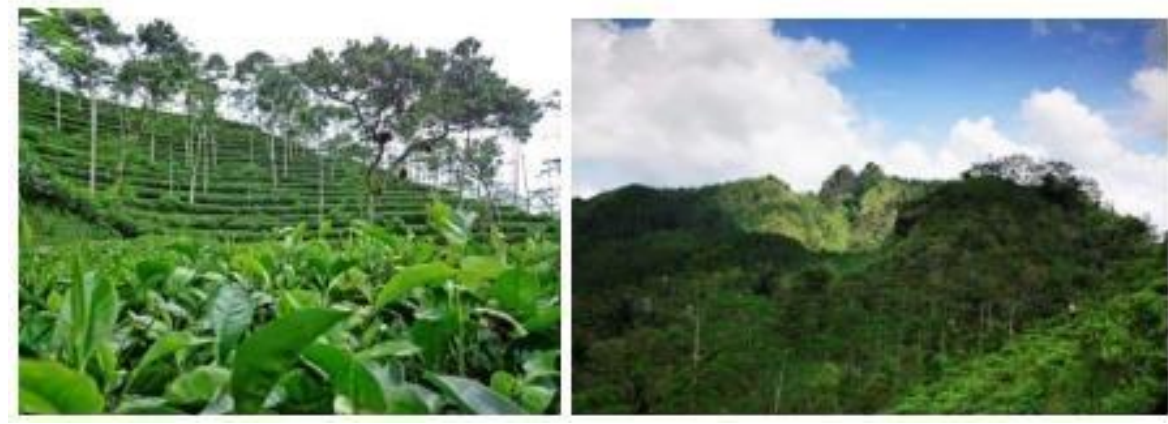

\section{Gambar 4 Kebun Teh Nglinggo Desa Pagerharjo}

Potensi alam di Desa Pagerharjo yang kedua adalah Air Terjun Watujonggol Nglinggo. Air terjun tersebut dekat dengan kebun teh Misi. Air terjun menjadi destinasi wisata kedua setelah kebun teh, karena lokasinya lebih rendah. Keistimewaan dari air terjun Watujonggol adalah lokasinya yang unik. Wisatawan yang akan menuju lokasi, harus jalan kaki di hutan terlebih dahulu. Potensi alam di Desa Pagerharjo yang ketiga adalah Air Terjun Cibirul Ngentak. Air terjun merupakan destinasi wisata yang baru saja dikomersialkan. Sebelumnya air terjun menjadi tempat wisata tersembunyi di Pedukuhan Ngentak. Keistimewaan dari air terjun Cibiru adalah lebar aliran terjun yang lebar namunpendek, sehingga banyak di gunakan para wisatawan untuk berendam.

Selain potensi wisata alam, berdasarkan hasil wawancara dengan Kepala Dinas Pariwisata kabupaten Kulon Progo Bapak Joko Mursito menyatakan bahwa, kearifan lokal yang terdapat di desa Pagerharjo sangat banyak, diantaranya guyup rukun dan gotong royong dalam pelaksanaan kegiatan yang 
ada dalam lingkup masyarakat, nguri- uri tradisi mulutan, suronan, tradisi budaya lengger tapeng, dan masih banyak lagi, sedangkan dari segi kuliner ada butil daun talas, geblek dan masih banyak lagi yang manahal tersebut masih bisa disaksikan dan dinikmati sampai saat ini.

Wisata budaya di Desa Pagerharjo diwujudkan dengan banyaknya potensi kesenian berupa seni tari, seni rupa dan seni pertunjukan. Diantaranya reog, jathilan, incling, angguk, campur sari, kethoprak, pendalangan dan yang menjadi ciri khas adalahtari lengger tapeng.

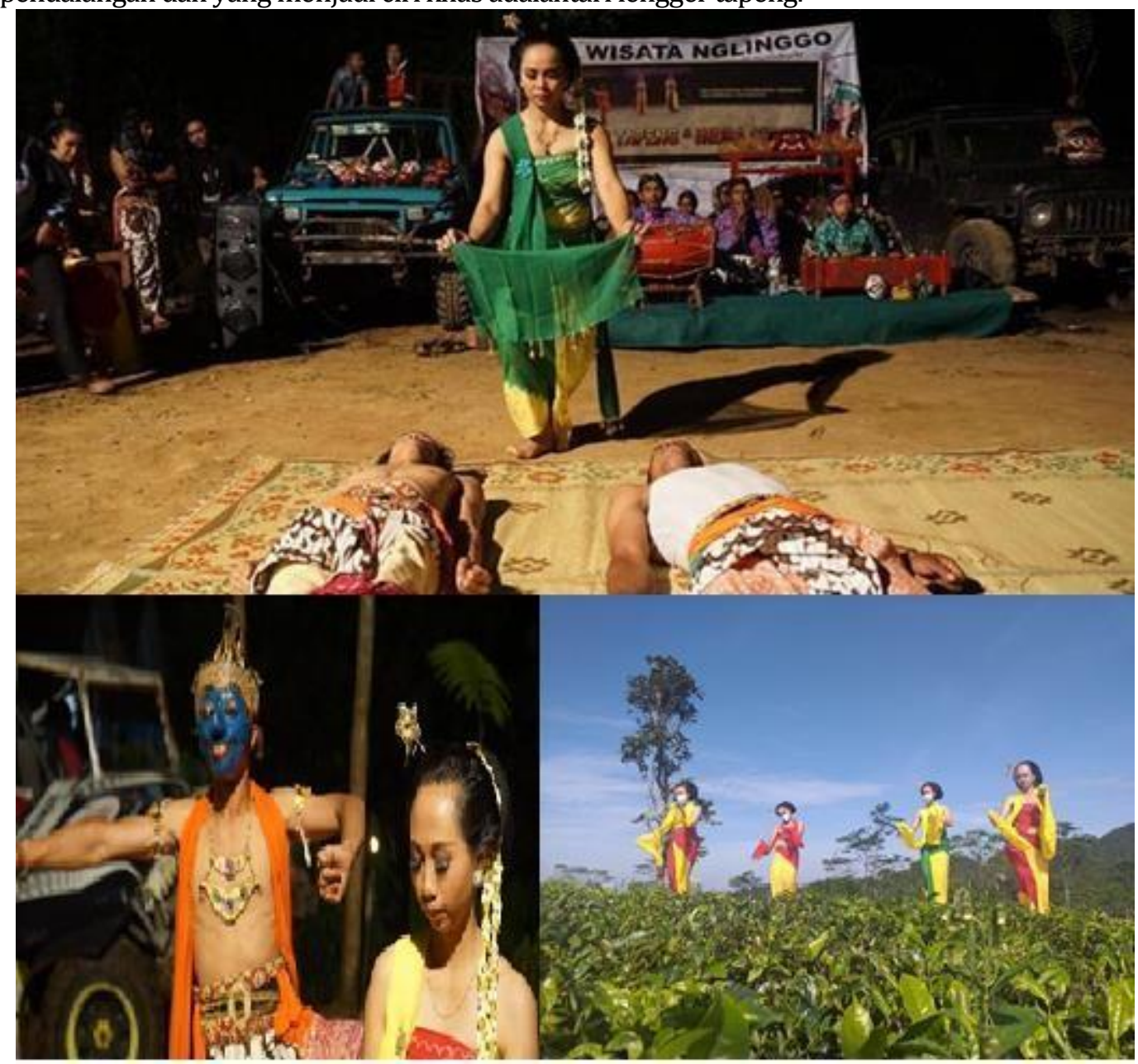

\section{Gambar 5 Tari Lengger Tapeng, Nglinggo Desa Pagerharjo}

Tari Lengger Tapeng merupakan seni pertunjukan yang berasal dari dusun Nglinggo, Desa Pagerharjo. Tarian ini menggunakan topeng dan melibatkan beberapa penari dengan berbagai macam karakter. Seperti bidadari, hanoman, raksasa, hingga beberapa makhluk lainnya. Lengger, artinya tari dan Tapeng itu Tayub Topeng, makai topeng. Karena para penarinya memakai topeng ketika menari. Tarian ini termasuk langka dan jarang ditemui karena berasal dari dusun setempat, Nglinggo. Bukan hanya sekedar warisan budaya, tarian ini juga memiliki beberapa makna. Jer basuki mawa bea, yang artinya membutuhkan sebuah modal untuk mencapai sebuah kesuksesan dalam pepatah Jawa. Lengger Tapeng, juga menjadi salah satu bentuk ungkapan penebus nazarbagi masyarakat di Desa Nglinggo.

Hal ini seperti yang diungkapkan Kepala Dusun/Dukuh Nginggo bapak Herry yang menyatakan bahwa "Kalau warga sini punya doa, atau nazar, biasanya Lengger Tapeng ini jadi nazarnya. Digelar semalaman, mulai dari jam 8 malam. Selesainya bisa pagi dini hari. Doa yang dipanjatkan bermacammacam. Mulai dari meminta rezeki, menyekolahkan anak, hingga cepat panen. Ini karena mayoritas 
penduduk adalah petani.Dulunya, tarian ini merupakan media penarik masyarakat setempat untuk menyebarkan Agama Islam oleh Sunan Kalijaga.

Pedapat di atas diperdalam oleh pendapat PJ Lurah Pagerharjo Bapak Jumaryadi yang menyatakan bahwa kesenian tari lengger tapeng merupakan khas kearifan lokal dusun nginggo Pagerharjo, yang mana sekarang telah berkembang dan menyebar di beberapa dusun lainnya di Desa Pagerharjo dan telah berdiri paguyubah-paguyuban gunamelestarikan kearifal lokal lengger tapeng.

Kesenian Tari Lengger tidak lebih dari bentuk kesenian tari erotic (Tayub). Akantetapi banyak pendapat lain yang menyatakan bahwa Tari Lengger atau Tayub padaawalnya merupakan bentuk kesenian yang dipersembahkan untuk upacara sakral. TariLengger dianggap bisa mendatangkan kekuatan-kekuatan magis yang pada gilirannyamendatangkan rasa ayem tentrem masyarakat dan juga bagi kasuburan tanah. Tidakmengherankan jika kemudian muncul berbagai kepercayaan dengan adanya Tari Lenggerini. Hal yang sering dipercaya misalnya jika ada Tari Lengger sedang melakukan pertunjukan, maka jika di tempat pertunjukan ada anak kecil yang rewel atau sakit anakkecil tersebut diciumkan ke pipi penari lengger. Dengan demikian mereka percaya bahwakekuatan magis yang ada pada diri Lengger akan mempercepat kesembuhan si anak.Banyak juga yang memberikan bayi atau anak-anaknya agar dipangku atau ditimang-timang penari Lengger dengan harapan si bayi tidak diganggu oleh kekuatan (ruh) jahat.

Selain tarian, terdapat pula kearifan lokal desa Pagerharjo dalam bentuk kuliner antara lain Buntil Daun Talas. Buntil adalah panganan tradisional yang sangat terkenal didataran Jawa. Jika pada umumnya buntil berbentuk gumpalan berisikan campuranmakanan yang dibalut dengan menggunakan daun papaya, maka di Desa Pagerharjo dapatditemukan buntil yang memakai daun talas sebagai pembungkus isiannya. Buntil daun talas menjadi salah satu makanan khas tradisional Desa Pagerharjo yang rasanya tidak kalah enak dengan buntil daun papaya. Untuk membuat daun talas, orang Pegerharjo biasanya memilih daun talas yang masih muda. Sedangkan untuk isiannya bisa berupa parutan kelapa, udang asin, dan biji petai. Pembuatan makanan berbahan dasar sayuran sangat mudah dan hanya memerlukan peralatan dapur yang sederhana. Buntil daun talasyang sudah siap santap biasanya disajikan bersama kuah santan berisikan cabe dan rempah lain sehingga menciptakan warna kemerahan.

Selain buntil ada juga geblek. Bentuk dari geblek tergolong sangat unik. Jika dilihat seperti angka delapan atau seperti gabungan 3 atau 4 cincin membentuk rantai. Geblek memiliki tekstur kenyal seperti cireng. Tetapi rasanya jauh berbeda dengan cireng. Geblek memiliki rasa gurih, karena menggunakan singkong. Bahan pokok pembuatan geblek adalah pati atau biasa disebut tepung kanji atau tepung tapioka. Pati dibuat dari sari singkong yang sudah mengendap.

\section{Aspek yang harus dipertimbangkan dalam perencanaan pengembangan wisatadi Desa Wisata Pagerharjo}

Berdasarkan Undang-Undang Kepariwisataan Nomor 10 Tahun 2009, defisini dari kepariwisataan adalah keseluruhan kegiatan yang terkait dengan pariwisata dan bersifat multidimensi serta multidisiplin yang muncul sebagai wujud kebutuhan setiap orang dan negara serta interaksi antara wisatawan dan masyarakat setempat, sesama wisatawan, Pemerintah, Pemerintah Daerah, dan pengusaha. Perwujudan Kerjasamamultidimensi dan multidisiplin dalam pembentukan atau pengembangan pariwisata dinilai akan mampu menggerakkan berbagai bentuk perkembangan wilayah, sepertipeningkatan berbagai kualitas sarana dan prasarana yang dapat menunjang kegiatan wisata seperti jalan, drainase, halte, dan sebagainya. Pembangunan kepariwisataan diwujudkan melalui pelaksanaan rencana pembangunan kepariwisataan dengan memperhatikan keanekaragaman, keunikan, dan kekhasan budaya dan alam, serta kebutuhan manusia untuk berwisata. 
Terdapat 3 aspek penting yang menjadi dasar dalam perencanaan pengembanganpariwisata yang disingkat dengan 3A (atraksi, amenitas, aksesbilitas). Aspek 3A merupakan syarat minimal bagi pengembangan sebuah destinasi wisata. Setiap destinasiwisata sudah pasti mempunyai keunikan dan ciri khasnya masing-masing yang membuatbanyak orang tertarik untuk mengunjungi lokasi wisata tersebut. Di lain sisi, faktor amenitas dan aksesbilitas akan menjadi kunci bagi keberlangsungan wisatawan dalam menikmati pengalaman berwisata. Ketiga faktor ini memiliki peran penting dalam membangun pengalaman berwisata yang nyaman serta menyenangkan bagi wisatawan. Adapun secara terperinci aspek yang harus dipertimbangkan dalam perencanaan pengembangan wisata di Desa Wisata Pagerharjo dapat diuraikan sebagai berikut:

\section{Rendahnya SDM masyarakat dalam pengembangan desa wisata}

Masyarakat di desa wisata Pagerharjo sebagaian besar berlatar belakang pendidikan yang rendah yaitu lulusan SD dan SMP, dengan mata pencaharian sebagai petani teh,kopi, dan cengkeh. Lemahnya SDM masyarakat tersebut menjadikan desa wisata dikelola secara parsial tanpa memiliki arah pengembangan dan perencanaan desa wisata yang potensial dan unggulan di Kulon progo dengan melibatkan peran serta masyarakat secara keseluruhan. Keterlibatan masyarakat secara keselurahan dapat dilibatkan dalam penggalian potensi wisata alternatif yang dapat menunjang pengembangan desa wisata seperti 1) wisata edukasi memanen/pembuatan teh,kopi, dan gula jawa, 2) wisata kesenian lengger dan tepeng , 3) wisata edukasi membuat kerajinan, 4) wisata edukasi membuat batik, 4) wisata kuliner makanan lokal, dan 5) Rumah warga belum termanfaatkan sebagai homestay, sehingga potensi wisata alternatif tersebut dapat melengkapi keberadaan wisata kebun teh dan Curug Watu Jonggol dan wisata lainnya dalam bentuk pengemasan paket wisata

\section{Tata kelola kelembagaan desa wisata yang tidak baik}

Kelembagaan yang di bentuk secara parsial menjadikan permasalahan tersendiri bagipengelola desa wisata di Pagerharjo, hal tersebut akibat dari Pertama, kurangnya persiapan sumber daya manusia (SDM) pengelola, baik dari sisi pengetahuan atau keterampilan dalam mengelola desa wisata. Kedua, lemahnya pengawasan padapengelolaan, terutama manajemen finansial, dan kurangnya rasa memiliki. Ketiga motivasi dari pengelola yang rendah dan tidak memiliki perencanaan pengembangandesa wisata. Keempat lembaga yang di bentuk belum memiliki badan hukum sehinggasangat sulit untuk mengakses pendanaan dari donatur pemerintah maupun swasta. Kelima pedagang tidak tergabung dalam satu kelembagaan.

\section{Rendahnya optimalisasi produk lokal (makanan, kerajinan, kesenian)}

Potensi lokal baik berupa makanan tradisional, kerajinan, dan kesenian di Desa Pagerharjo selama ini belum dikelola dengan baik dalam menunjang keberadaan desa wisata. Hal tersebut akibat dari pertama, kurangnya kesadaran masyarakat bahwa potensi tersebut dapat menjadi wisata alternatif. Kedua, Tidak adanya peran pendamping pemerintah/swasta dalam mengembangkan wisata alternatif. Dan ketigaadanya rasa kekhawatiran dari masayarakat apakah potensi tersebut dapat bernilai jual.

\section{Tidak adanya perencanaan partisipatif dalam pengembangan desa wisata}

Peran pemerintah Desa sangat diperlukan dalam perencaaan dan pengembangan desawisata Pagerharjo baik untuk perencanaan jangka pendek, menengah dan panjang. Ketiadaan keterlibatan pemerintah desa dapat menjadikan desa wisata di Pagerharjo berjalan stagnan dan kurangnya sarana prasarana pendukung. Selama ini arah pengembangan di lakukan secara parsial dengan berdasarkan 
pemasukan dan saran dari pengunjung. Permasalahan- permasalahan tersebut akibat dari pertama, Kemampuan SDM masyarakat dan pengelola terbatas dalam membuat perencanaan. Kedua ketiadaan SDM yang mampu memotret potensi desa wisata (profil Desa Wisata) . Ketiga tidak adanya SDM yang mampu membuat perencaaan dalam gambar masterplan. Persoalan - persoalan tersebut di atas merupakan persoalan yang harus segera di selesaikan supaya desa wisata Pagerharjo dapat menjadi daerah tujuan wisata unggulan di Kabupaten Kulon progo tanpa meninggalkan keunikan dan normanorma tradisi yang kental serta kekayaan alam berdasarkan nilai-nilai kearifan lokal masyarakat dalam mendukung kabupaten Kulon progo sebagai The Jewel of Java.

\section{Faktor pendukung dan penghambat pengembangan wisata berbasis kearifan lokal di Desa Wisata Pagerharjo}

Faktor pendukung pengembangan wisata berbasis kearifan lokal di Desa Wisata Pagerharjo diantaranya adalah kultur masyarakat yang sudah melekat dengan sikap sopansantun serta ramah tamah kepada siapapun yang datang. Sebagaimana diungkapkan olehKepala Dinas Pariwisata kabupaten Kulon Progo Bapak Joko Mursito bahwa Desa WisataPagerharjo memiliki banyak keunikan diantaranya satusatunya daerah di DIY yang memiliki kebun teh, kearifan lokal dalam bentuk seni budaya lengger tapeng yang manaitu merupakan tarian khas dusun nginggo yang terus ada sampai saat ini. Selain itu banyak kuliner yang dapat dijadikan salah satu paket wisata dan menjadi ciri khas untuk identitasdesa wisata. Selain itu Desa Wisata Pagerharjo merupakan pintu masuk utama kawasan Borobudur Higlind yang merupakan destinasi wisata yang berada dalam kawasan BadanOtorita Borobudur, sehingga desa wisata Pagerharjo sangat potensial untuk mengembangkan kearifan lokal sebagai daya tarik wista, salah satunya dari segi budaya.Sedangkan menurut pak Wakidi selaku ketua paguyuban seni tari lengger Tapeng, kesenian tari ini sangat diminati oleh wisatawan yang datang ke Desa Pagerharjo. Mulaitahun 2020 juga sudah dibentuk lembaga seni dan budaya yang dikelola oleh muda-mudi desa Pagerharjo untuk mempelajari dan mengembangkan serta melestarikan seni tari Lengger Tapeng. Selain.

Faktor penghambat pengembangan wisata berbasis kearifan lokal di Desa Wisata Pagerharjo menurut Kepala Dinas Pariwisata kabupaten Kulon Progo Bapak Joko Mursito bahwa Desa Wisata Pagerharjo diantaranya adalah belum adanya blueprint pemetaan potensi wisata yang ada di desa Pagerharjo, sejarah, spot pariwisata dan pemberdayaan masyarakat dari hulu ke hilir yang belum berjalan. Seperti misalnya pengembangan produk teh, itu belum ada pengolahan mulai dari penanaman, perawatan,pengolahan hasil panen sampai dengan pemasaran itu belum terkoneksi dan terstruktur sehingga diperlukan pembinaan dan penataan. Selain itu faktor komunikasi antara masyarakat, pemerintah desa dan semua elemen yang terlibat didalamnya perlu ditingkatkan sehingga terbentuk komunikasi yang haarmonis dan tidak saling bertentangan, sehingga tujuan dari pengembangan wisata dapat dipahami dan dimaknai secara bersama-sama. Sehingga Pokdarwis bisa berfungsi sebagaimana fungsinya, desa dapat berperan sebagaimana posisinya dan juga masyarakatnya.

Faktor penghambat lainnya disampaikan oleh pak Wakidi selaku ketua paguyubanseni tari lengger Tapeng di dusun Nglinggo bahwa lengger tapeng sebagai budaya khas nglinggo saat ini telah berubah fungsinya seiring dengan meningkatnya pemahaman masyarakat terhadap agama, sehingga masyarakat tidak lagi mementaskan lengger tapengsebagai bentuk dari rasa syukur dan nazar sebagaimana dahulu, melainkan pementasan hanya sekedar untuk pemenuhan kebutuhan wisata saja. Karena kalau kembali pada ruh lengger tapeng itu tetap dilestarikan sebagaimana bentuk aslinya akan memicu pertentangan ditengah masyarakat yang kian sadar akan agama, sehingga pemestasan lengger tapeng saat ini sudah tidak lagi menggunakan bakaran kemenyan dan uborampe lainnya, untuk menggantikannya sekarang digunakan bakaran tatal pohon pinus dan pementasan saat ini hanya sekedar tarian untuk memenuhi permintaan wisatawan. 
Sedangkan menurut Kepala Dusun/Dukuh Nginggo bapak Herry yang menyatakan bahwa terjadi gesekan dalam kepengurusan dan tatakelola desa wisata Pagerharjo, dimana sebelum desa wisata Pagerharjo terbentuk dusun Nglinggo sudah lebih dahulu dikenal oleh masyarakat sebagai desa wisata Nglinggo yaang terbagi menjadi Nglinggo Barat dan Nglinggo Timur. Desa wisata Nglinggo telah dibentuk oleh masyarakat sejak taahun 2002-2003 dengan bentuk pengelolaan serta pembangunan sarana prasarana dilakukan melalui swadaya masyarakat secara gotongroyong, sehingga masyarakat desa Nglinggo menginginkan bahwa pengelolaan desa wisata Nglinggo tetapberdiri sendiri walaupun secara administrasi masuk dalam salah satu dusun yang ada di Desa Pagerharjo.

\section{Daftar Referensi}

Akers, R., \& Jennings, W. 2011. Social Learning Theory. Thousand Oaks: Sage.

Publications. Alwisol.

Alfred, D. Chandler, Jr .2012. Strategy and Structure: Chapters in The History of The Iindustrial Enterprise. Cambridge Mass: MIT Press

Arikunto, Suharsimi. 2015. Prosedur Penelitian Suatu Pendekatan Praktek. Jakarta: PT.Rineka Cipta. Creswell, Jhon W. 2013. Research Design Pendekatan Kualitatif, Kuantitatif, dan.

Mixed. Yogyakarta: Pustaka Pelajar.

David, Fred R. 2010. Manajemen Strategis: Konsep. Jakarta: PT Indeks.

Hunger, J. David dan Wheelen, Thomas L. 2003. Manajemen Strategis. Yogyakarta:Andi.

Mack, N., Woodsong, C., MacQueen, K., Guest, G., \& Namey, E. 2015. InDepthInterviews. Qualitative Research Methods: A Data Colector's Field Guide.

Marpaung, Happy. 2007. Pengetahuan Kepariwisataan. Bandung: Alfabeta. Maryani. 1991. Pengantar Geografi Pariwisata. Bandung: Jurusan Pendidikan.

Geografi FPIPS IKIP.

Miles, Matthew B dan Huberman, A. Michael. 2012. Analisis dan Kualitatif: BukuSumbertentang Metode-Metode Baru. Jakarta: UI Press.

Moleong, Lexy. 2018. Metode Penelitian Kualitatif. Bandung: PT. Remaja Rosdakarya. Muhadjir, Noeng, 2010, Metode Penelitian Kualitatif, Jogja: Rake Sarasin.

Nasution. 2013. Metode Penelitian Naturalistik Kualitatif. Bandung: Tarsito. Nilasari, Senja. 2014. Manajemen Stratgei Itu Gampang. Jakarta. Dunia Cerdas.

Pendit, S Nyoman. 2013. Ilmu Pariwisata Sebuah Pengantar Perdana. Jakarta: PT.Pradnya Paramitagt.

Rangkuti, Freddy. 2013. Strategi Promosi Yang Kreatif \& Analisis Kasus IntegratedMarketing. Communication. Jakarta: PT Gramedia Pustaka Utama.

Singarimbun, Masri. 2013, Metode Penelitian Survei, Jakarta: LP3ES Soemanto, Wasty. 2017, Pendidikan Wiraswasta, Jakarta: Bumi Aksara.

Sukmadinata, Nana Syaodih. 2015. Metode Penelitian Pendidikan. Bandung: Rosda.Suwardjoko. 2017. Analisis Kota dan Daerah, Bandung: Penerbit ITB.

Yoeti, A Oka. 2012. Perencanaan dan Pengembangan Pariwisata. Jakarta: PT PradnyaParamita. 